\title{
Settlement Of Bad Loans Through Debt Payment Obligation Submitting Institutions (PKPU)
}

\section{Dini Syakina Siregar}

Sumatera University Faculty Of Law. E-mail: dinisiregar@gmail.com

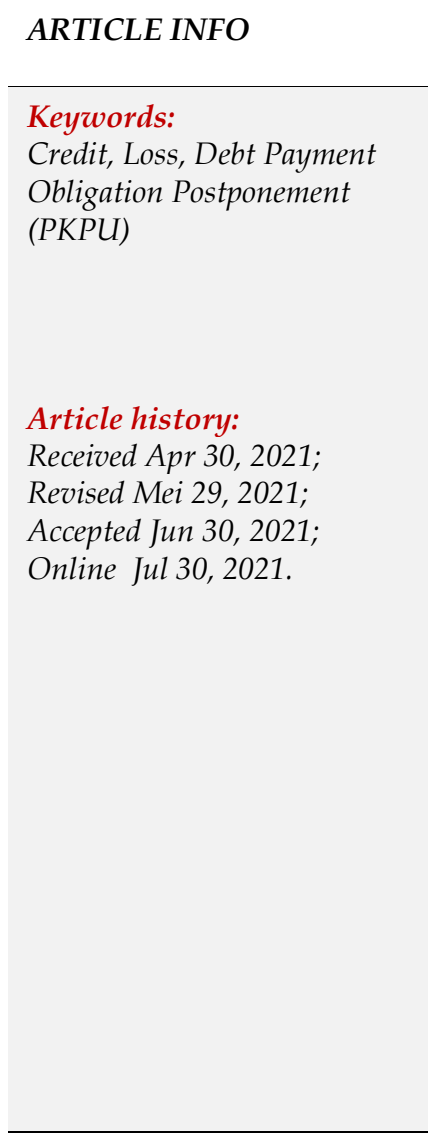

\begin{abstract}
In order to enter the era of globalization and face the growth of the national economy, the banking sector is one sector that must be developed and utilized optimally. Especially through the provision of facilities provided by the banking sector for the community. The problem formulated in writing this thesis is how to handle bad loans in the banking environment, then discussed again What is the legal relationship between the Suspension of Debt Payment Obligations (PKPU) and bad loans, then discussed about How to settle bad loans through the Debt Payment Obligation Suspension Agency. (PKPU).The research that will be conducted is normative legal research. Normative research based on primary and secondary legal materials, namely the intarization of regulations relating to the writing of the author's thesis. The data collection technique was carried out by means of library research (library research). From the data that has been collected, both primary data and secondary data, then processed and analyzed using qualitative descriptive analysis techniques. Bad credit (Non Performing Loan / NPL) is where the credit cannot run as agreed in the credit contract agreement. Bad credit or credit failure can occur for many reasons. To avoid the occurrence of bad credit, it is necessary to control. Every loan disbursement of course has complied with banking regulations and is in accordance with sound credit principles. If indeed in the future, the credit develops into bad credit, then PKPU will be an alternative for the debtor and creditor in repaying the credit. As long as PKPU lasts, debtors cannot be forced to pay their debts. All execution actions that have been assessed to obtain debt repayment, must be suspended.
\end{abstract}

This is an open access article under the CC BY-NC license.

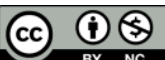

\section{Introduction}

All developed and developing countries must want all the people in a country to live prosperously and prosperously. Prosperity and prosperity can only be achieved if all the pillars of the economy in the country can run well. Especially at this time which has entered the era of globalization, every country must be able to compete with other countries to create a good economic growth.

In order to enter the era of globalization and face the fast-moving national economic growth, the banking sector is one sector that must be developed and utilized optimally in the implementation of this development in order to realize equitable distribution of people's income. Especially through the provision of facilities provided by the banking sector to the community, such as the provision of credit facilities that can be utilized by economic actors to develop and enlarge their businesses, both directly and indirectly, which can reduce 
unemployment and assist income distribution. in society. The word 'bank' in people's lives is certainly not foreign. It's just that it needs to be remembered that the introduction of banks from some people is only limited in a narrow sense. People know that banks are still limited to those related to savings or credit. Actually, it's still a natural situation if some of our people don't know banks, even though every day they actually have contact with banking products.

Public ignorance about banks as a whole is more due to the lack of information and knowledge provided by various parties to various levels of society, both those who live in cities and in remote rural areas. As described above, the banking world does play a very important role in people's lives. . It can be felt that the activities carried out by the community are actually always related to banks. Is it that people are happy because they get money and then save in the bank, or even sad because they don't have money to meet urgent needs, so people also have to go to the bank to borrow money from the bank (credit system).

Bank as an intermediary function, theoretically a bank may not have sufficient capital in its business because the funds used in providing credit facilities (lending) use public funds that have been collected (funding). The basic difference between public funds deposited in banks and credit facilities is that deposits with banks can be withdrawn at any time based on an account opening agreement, while credit facilities provided by banks to the public cannot be withdrawn at any time. Therefore, in many cases, banks are unable to fulfill their obligations to return public funds deposited in banks (rust). because the funds are still used by other people in the form of credit which can only be requested after the due date of payment based on the credit agreement so that it cannot be requested to be returned at any time.

The provision of credit facilities by banks should ideally be based on financial factors covered by 3 (three) pillars, namely business prospects, performance and capabilities of prospective debtors. However, by taking into account the existence of prudential banking principles, the financial factor alone is not enough to provide confidence that the credit facility will return safely and profitably. Even though collateral is basically a second way out, the direction of recent developments in banking credit outside of consumer credit has led to the collateral factor as the dominant variable that can provide confidence to banks.

In the credit facility, analysis of the facts and data accompanying the debtor in submitting his application is part of the factors that support the analysis and conclusion that "guarantee" is the creditor's "belief" that the credit provided can be returned on time. In other words, the term "collateral" which is termed "credit guarantee" is defined as confidence in the ability and ability of the debtor to pay off his debts in accordance with the agreement.

To obtain such confidence, before granting credit, banks must make the same assessment of the character, ability, capital, collateral, and business prospects of debtor customers. Bearing in mind that collateral is one of the elements of granting credit, if based on other elements it can be obtained confidence in the ability of the debtor customer to repay the debt, the building can only be in the form of goods, projects, or collection rights financed with the credit in question. Land whose ownership is in the form of girik, petuk, and others of the like can be used as collateral. Banks are not required to ask for collateral in the form of goods that are not directly related to the project being financed, which is commonly known as additional collateral.

The implementation of development supported by a stable level of economic growth and market conditions is an ideal condition that is expected by all parties, but sometimes this is not always the case. The decline in currency exchange rates, the continued increase in loan interest rates accompanied by a decline in people's purchasing power (inflation) greatly affected the economy in general. Conditions like this will have an impact on the decline in the ability to pay debtors of a bank. 


\section{Method}

The research that will be conducted is normative legal research20. Normative legal research is mainly carried out for research on legal norms in the sense of legal science as the science of rules or if law is seen as a rule whose formulation is autonomous without being associated with society. Normative research based on primary and secondary legal materials, namely the intarization of regulations relating to the writing of the author's thesis.

It is carried out by means of library research, which is a series of attempts to obtain data by reading, reviewing, clarifying, identifying, and understanding legal materials in the form of legislation and literature books that have relevance to the research problem. . The results of the assessment activities are then systematically summarized as the essence of the results of the document study review. The purpose of this documentation technique is to search for conceptions, theories, opinions or findings related to research problems.

From the data that has been collected, both primary data and secondary data, then processed and analyzed using qualitative descriptive analysis techniques, namely by describing all data according to quality, and the nature of symptoms and legal events by linking existing legal materials. After that, the data is presented in a descriptive analysis by describing it systematically and comprehensively, so that it can answer the problem. ${ }^{14}$

\section{Analysis And Results}

\subsection{Handling Of Nad Loans In The Banking Environment}

\section{a. Credit as a form of credit regulatory agreement in the banking environment}

In Law Number 10 of 1998 concerning Banking, it does not construct a legal relationship between the granting of credit and the customer borrowing the funds. It's just that we can know that the granting of credit is based on an agreement or loan agreement between the bank as a creditor and another party borrowing funds as a debtor within a certain period that has been agreed or mutually agreed upon and will repay the debt with a certain amount of interest, compensation. , or profit sharing.

The consensual nature of a credit agreement is the first characteristic that distinguishes it from a real money lending agreement. A credit agreement is a loan agreement of money under English law which can be real or consensual, but is not a real loan agreement under Indonesian law. For a credit agreement that clearly states: the tough conditions cannot be denied that the agreement is a consensual agreement.

Credit provided by banks to debtor customers cannot be used freely for certain purposes or purposes by debtor customers, as is done by money borrowers or debtors in ordinary money lending agreements. In a credit agreement, credit must be used in accordance with the purpose set out in the agreement and use that deviates from that purpose gives the bank the right to terminate the credit agreement unilaterally and to immediately and at the same time collect all debits or outstanding credits. What distinguishes a bank credit agreement from a loan agreement is the terms of how it is used. Bank credit can only be used in a certain way, namely by using a check or book-entry order.

\section{b. Credit regulations in the banking environment}

There are many laws and regulations like this. This is caused by a juridical character of the banking business, namely the business sector which is full of regulations and implementation instructions (Heaviy regulated business). Among the laws and regulations whose level is below the law which also regulates credit can be classified as follows: 
1) Government regulations

2) Legislation by the Minister of Finance

3) Legislation by Bank Indonesia, namely Bank Indonesia Regulation No.14/22/PBI/2012 dated December 21, 2012 concerning the Provision of Credit or Financing and Technical Assistance in the Context of Developing Micro, Small, and Medium Enterprises.

4) Other laws and regulations

c. Factors causing bad credit in the banking environment

Bad credit is a condition where the customer is unable to pay part or all of his obligations to the bank as agreed. Loans are classified as bad loans if they meet the following criteria:

1) Based on business prospects, namely:

a) business continuity is very doubtful,

b) industry is experiencing a decline and is difficult to recover,

c) market loss in line with declining economic conditions.

d) very weak management.

e) there was a labor strike which was very difficult to overcome.

2) Based on the debtor's finances, namely:

a) suffered a great loss,

b) the debtor is unable to fulfill all obligations and business activities cannot be maintained,

c) The debt-to-equity ratio is very high,

d) The new loan is used to cover operating losses.

3) Based on the ability to pay, namely:

a) there is arrears payment tree and flower which has beyond 270 days,

b) There is no documentation of credit or binding of collateral.

Bad credit factors are things that contribute to a situation where the customer is unable to pay part or all of his obligations to the bank as agreed.

\section{d. Handling bad loans in the banking environment}

Bad credit (Non Performing Loan / NPL) is where the credit cannot run as agreed in the credit contract agreement. Bad credit or credit failure can occur due to many things, however, the provision of credit with the prudence principle contained in the $5 \mathrm{C}$ principle will greatly reduce the possibility of bad credit. These principles are:

1) Analysis of capacity (capacity) will anticipate the possibility of bad credit caused by the absence / loss of debtor's ability to pay. This capacity must be measurable in magnitude or continuity according to the credit load (installment) that will be borne. This capacity is the debtor's ability to generate income, which can be in the form of salary income (for individual debtors an employee) or net profit (for entrepreneurial or corporate debtors).

2) Capital owned and invested in a business, will be able to reflect the seriousness of the debtor in running his business. In relation to bad loans, the amount of capital owned (especially in cash) / can be in the form of cash, savings balances, time deposits) will be able to be a backup (back-up) for installments when the capacity is impaired; The greater the capital owned, the longer the installment reserve that can be handled.

3) Collateral is needed in order to anticipate losses that occur due to bad loans. This guarantee is expected to have sufficient value if

\subsection{Legal Relationship Between Donation Of Debt Payment Obligations (Pkpu) And Non Loans}

a. Definition of postponement of debt payment obligations (PKPU) 
The Institution for Suspension of Debt Payment Obligations (PKPU) and the Bankruptcy Institution are two institutions that complement each other in efforts to regulate debt payments. These two institutions are part of the national civil law system, particularly commercial law. These two institutions can be used by debtors who have difficulty paying their debts. Besides being able to be used by debtors, these institutions can also be used by creditors, and agencies authorized by law to act for and on behalf of creditors.

Suspension of Debt Payment Obligations (PKPU) in Dutch is called séance van betaling and in English it is called suspension of payment. Suspension of Debt Payment Obligations (PKPU) comes from the old Germania law and is only granted in extraordinary cases by the Court, for example in a state of war, the court gives permission to the bank to postpone the payment of its debts to customers within a certain period of time according to the Act.

In Indonesia, initially the Suspension of Debt Payment Obligations (PKPU) was regulated in the bankruptcy regulations (failli semens verordening S 1905 Number 217 jo S 1906 Number 348) which only applied to traders. Then in 1927 there was a change that gave the debtor the right to apply for a PKPU in order to apply for full payment of his debt to the creditor. Subsequently, in 1938 a second amendment was made which allowed eligible debtors to apply for a PKPU as a prelude to a forced peace (dwang accord). This is intended to provide the possibility of greater payments to creditors who agree to the settlement.

What is meant by suspension of payment or surceance van beataling is a period given by law through a commercial judge's decision in which during that period creditors and debtors are given the opportunity to discuss ways to pay their debts by drawing up a payment plan. all or part of the debt, including if necessary to restructure the debt. So the Suspension of Debt Payment Obligations (PKPU) is actually a kind of moratorium in a legal moratorium.

\subsection{Conditions for Postponing Debt Payment Obligations (PKPU)}

Applications for Suspension of Debt Payment Obligations (PKPU) submitted to the Commercial Court, whether submitted by debtors or creditors, must meet formal requirements and substantial requirements. Formal requirements are completeness of case files, including receipts for payment of court fees. Prior to the case, the Postponement of Debt Payment Obligation (PKPU) is recorded in the register or deregister. While the substantial requirements that must be met and proven by the PKPU applicant at trial.

\section{a. Formal Terms}

1) In the event that the debtor is an individual, it is obligatory to file an application letter with sufficient stamp duty which is signed by the debtor and an attorney as their proxy by attaching:

a) A list containing the nature, amount of receivables and debtors' debts along with sufficient evidence.

b) Peace plan.

c) Photocopy of card/advocate legalized.

d) Special power of attorney.

e) A legalized photocopy of the applicant's ID card.

f) Letter of approval from husband/wife.

g) List of assets.

h) The balance sheet if you have a company.

2) In the event that the debtor is a corporate legal entity, it is obligatory to submit an application letter with sufficient stamp duty which is signed by the debtor and an attorney as proxy by attaching:

a) A list containing the nature, amount of receivables and debtors' debts along with sufficient evidence. 
b) Peace plan.

c) Photocopy of card/advocate legalized.

d) Special power of attorney.

e) Legalized company registration certificate.

f) GMS decision deed.

g) The latest balance sheet.

h) Name and address of debtor and creditor.

i) Deed of establishment or amendment to the articles of association made by a notary.

j) Photocopy of the decision letter for the legalization of the company's legal entity from the Ministry of Law and Human Rights.

3) In the event that the debtor is a social legal entity (foundation/association), it is obligatory to submit an application letter with sufficient stamp duty which is signed by the debtor and an attorney as proxy by attaching:

a) A list containing the nature, amount of receivables and debtors' debts along with sufficient evidence.

b) Peace plan.

c) Photocopy of card/advocate legalized.

d) Special power of attorney.

e) The decision of the management meeting that approved the submission of the PKPU application.

f) The latest balance sheet.

g) Name and address of creditor.

h) Deed of establishment or amendment to the articles of association made by a notary.

i) Photocopy of the decision letter for the legalization of the company's legal entity from the Ministry of Law and Human Rights.

b. Procedure for Suspension of Debt Payment Obligations (PKPU)

Usually PKPU applications are made with 2 motives as follows:

1) Debtors really want to restructure their debts. As stated in article 222 of the UUK that a debtor may apply to the commercial court to accept the PKPU of his debts if he is in a state of being unable or expected to be unable to continue paying his debts with the general intention of submitting a reconciliation plan which includes an offer to pay all or all of his debts. part of its debt to concurrent creditors. It is hoped that with the PKPU process, these debts can be restructured according to the wishes of the debtor and creditor.

2) As a fight against the bankruptcy petition from the creditor, it often happens that the PKPU application is submitted by the debtor as a defense against the bankruptcy petition filed by the creditor. Because, according to article 229 paragraph (3) of the UUK, if the petition for a declaration of bankruptcy and the petition for PKPU are examined at the same time, the PKPU petition must be decided first. In addition, at least for a temporary PKPU (for a maximum of 45 days), the court must immediately (without much room for interpretation) grant the temporary postponement of the payment of the debt by directly appointing a supervisory judge and appointing one or more administrators.

c. Legal Consequences of Suspension of Debt Payment Obligations (PKPU)

The legal consequences of PKPU based on the UUK are:

1) Debtors cannot take management actions on their assets without the approval of the management [article 240 paragraph (1)],

2) The debtor cannot be forced to pay his debts [article 242 paragraph (1)],

3) All executions that have started, are suspended [article 242 paragraph (1)],

4) All confiscations that have been determined to be void [article 242 paragraph (2)],

5) Debtors who are held hostage, released [article 242 paragraph (2)],

6) All executions and confiscations of objects guaranteed by pledge, fiduciary guarantees, mortgages, mortgages and mortgages on other objects are void [article 242 paragraph (3)], 
7) The debtor cannot be a plaintiff or defendant in a case regarding rights or obligations relating to his assets without the approval of the management [article 243 paragraph (3)],

8) PKPU does not apply to claims secured by a pledge, fiduciary guarantee, mortgage, mortgage, or other collateral rights for material rights [article 244 letter a],

9) PKPU does not apply to bills for maintenance, supervision or education costs that have to be paid [article 244 letter b],

10) PKPU does not apply to claims that are privileged to certain objects belonging to the debtor or to all debtor's assets that are not covered by letter b [article 244 letter c],

11) Debt payments may not be made, unless the payment of the debt is made to all creditors proportionally [Article 245],

12) All confiscations and executions of assets that are encumbered with collateral rights or privileges as well as those that are not encumbered, are suspended [article 246],

13) Receivables or debts taken over after the commencement of PKPU, cannot be reconciled [article 282 paragraph (2)],

14) The debtor cannot terminate the lease relationship [article 251],

15) The debtor has the right to terminate the employment relationship [article 252],

16) PKPU does not apply to the benefit of fellow debtors and guarantors [article 254]

d. Legal Relationship of Suspension of Debt Payment Obligations (PKPU) With Bad Credit

As a business full of risk, before providing credit, banks should conduct a thorough, thorough and thorough credit analysis based on actual and accurate data, so that banks will not be wrong in making decisions. Therefore, every lending must have complied with banking regulations and is in accordance with sound credit principles. Likewise, the granting of credit has also been based on an honest, objective assessment and is independent of the influence of parties with an interest in the credit applicant. The bank must believe that the credit that will be given can be repaid on time by the debtor's customer and will not develop into non-performing or nonperforming loans.

If indeed in the future, the credit develops into bad credit, then PKPU will be an alternative for the debtor and creditor in repaying the credit. Peace is the most essential element as well as the goal in a PKPU. Thus, there is no point in doing PKPU if the parties are not serious about implementing the peace, which is initiated by the debtor by submitting a composition plan. The parties in the sense of PKPU are the debtors together with the creditors, especially concurrent creditors.

\subsection{Settlement Of Non-Loading Loans Through The Institution For Suspension Of Debt Payment Obligations}

\section{a. Suspension of Debt Payment Obligations (PKPU) as a Debt Restructuring Agency}

As has been explained that the purpose of PKPU is to achieve a goal of peace, among others, through debt restructuring to its creditors, especially concurrent creditors. This is because peace in the PKPU (as well as peace in the bankruptcy process) does not apply to both separatist creditors and privileged creditors [article 244 UUK].

b. Bad Loans Settlement Mechanism through Postponement of Debt Payment Obligations (PKPU)

If according to the bank's considerations, it is impossible to save the problem credit and become smooth again through rescue efforts so that eventually the credit becomes bad, then the bank will take steps to settle or collect the problem or bad credit. The settlement or collection of nonperforming loans is a bank's effort to recover payments from customers or debtors and/or guarantors for bank loans that have become problematic or without liquidating the collateral. 
Although banks do not expect non-performing loans, all bank officials, especially those related to credit, must have the same view and perception in dealing with non-performing loans. Therefore, to resolve non-performing loans, it is necessary to use the following approach:

1) Banks do not allow or even cover up the existence of non-performing loans,

2) Banks must detect early non-performing loans or are suspected to be non-performing loans,

3) Handling non-performing loans or suspected to be non-performing loans must also be carried out early and as soon as possible.

4) Banks do not settle non-performing loans by increasing the credit limit or interest arrears and capitalizing the interest arrears or commonly known as the practice of credit platforming.

\section{c. Legal Efforts Taken To Avoid Bad Credit}

To determine whether a credit is said to be problematic or bad is based on the collectibility of the credit. Collectability is the state of payment of principal or installments and interest on credit by the debtor and the level of possibility of receiving the funds back.

A credit classified as non-performing loans are loans classified as substandard credit, doubtful credit and bad credit. The term non-performing or non-performing loans has been used by the Indonesian banking world as a translation of problem loans, which are terms that are commonly used internationally. The emergence of problem loans in the banking world today, apart from indications that debtors do not want to pay their debts, is also seen in the procedures for implementing credit grants, which also have irregularities.

\section{Conclusion}

Bad credit (Non Performing Loan / NPL) is where the credit cannot run as agreed in the credit contract agreement. Bad credit or credit failure can occur for many reasons. To avoid the occurrence of bad credit, it is necessary to control. The technique of controlling bad loans can be interpreted as a determination of the terms of the procedure for consideration towards credit to eliminate the risk that the credit will not be paid off in full.

Every loan disbursement of course has complied with banking regulations and is in accordance with sound credit principles. Likewise, the granting of credit has also been based on an honest, objective assessment and is independent of the influence of parties with an interest in the credit applicant. If indeed in the future, the credit develops into bad credit, then PKPU will be an alternative for the debtor and creditor in repaying the credit. Peace is the most essential element as well as the goal in a PKPU.

The settlement or collection of non-performing loans is a bank's effort to recover payments from customers or debtors and/or guarantors for bank loans that have become problematic or without liquidating the collateral. As long as PKPU lasts, debtors cannot be forced to pay their debts. All execution actions that have been assessed to obtain debt repayment, must be suspended.

\section{References}

Badrulzaman, Mariam Darus. Various Business Laws, Bandung : PT. Alumni, Beck, Thorsten and Ross Levine, Legal Institutions and Financial Development, Working Paper, World Bank, Washington DC: 2003.

Fuady, Munir. Introduction to Business Law, Bandung: Citra Aditya Bakti, 2001. Ikhsan, Edy., and Mahmul Siregar, Research Methods and Legal Writing As Teaching Material, Medan : Faculty of Law, University of North Sumatra, 2009. 
Kuncoro, Mudrajad and Suharjono, Banking Management Theory and Applications, Yogyakarta: BPFE Publisher, 2002.

M., Sinungan., Fundamentals, Fundamentals and Techniques of Credit Management, Jakarta: PT. Bina Aksara, 1989.

Mulyono, Pudjo, Budgeting Bank, Yogyakarta: BPFE, 1996.

Mulyono, Teguh P., Commercial Credit Management, Yogyakarta : BPFE, 2001.

Soekanto, Soejono. Legal Research, Jakarta: UI Press, 1986.

Sihombing, Jonker. Bankers' Juridical Responsibilities for Bad Credit Customers, Bandung : PT. Alumni, 2009.

Sinaga, Syamsudin M. , Indonesian Bankruptcy Law, Jakarta : PT. Tatanusa, 2012.

Suyatno, Thomas, Fundamentals of Credit, Jakarta : PT. Gramedia Pustaka Utama, 2003.

Untung, H. Budi., Banking Credit in Indonesia, Yogyakarta: Andi Publishers, 2005.

Usman, Rahman. Legal Aspects of Banking in Indonesia, Jakarta : PT. Gramedia Pustaka Utama, 2001.

Wardoyo, Gatot, About the Clauses of the Bank's Credit Agreement, magazine Banks and Management, November-December 1992 Edition.

Widiyono, Tri. Credit Collateral in Financial Engineering ( Jakarta : Ghlmia Indonesia, 2009)

Andira M., Definition and Elements of Credit, quoted from www.bankirnews.com, last accessed on March 26, 2013.

Banking Law : Bank Credit II, quoted from http://studiade.wordpress.com, Last accessed on March 26, 2013.

Hwang;s blog, Roy Sanjaya's Legal and politix info, quoted from www.roysanjayablogspot.com, last accessed on March 19, 2013.

Bad credit, quoted from http://credit-ku.com, last accessed on March 26, 2013.

Understanding Credit, Functions, Elements, Kinds, Principles, Credit Defense According to Experts, quoted from www.sarjanaku.com, last accessed on March 26, 2013.

Causes of Non-Performing Loans (NPL), quoted from http://arsasi.wordpress.com, last accessed on March 26, 2013.

Bank Credit Agreement, quoted from http://stiebanten.blogspot.com last accessed on March 26, 2013. 